\title{
The Nonvolatile and Volatile Metabolites of Prangos ferulacea and Their Biological Properties*
}

\author{
Authors \\ Maurizio Bruno ${ }^{1}$, Vincenzo llardi ${ }^{2}$, Giulio Lupidi ${ }^{2}$, Luana Quassinti ${ }^{3}$, Massimo Bramucci ${ }^{3}$, Dennis Fiorini ${ }^{4}$, \\ Alessandro Venditti ${ }^{5}$, Filippo Maggi $^{3}$
}

Affiliations

1 Department of Biological, Chemical and Pharmaceutical Sciences and Technologies (STEBICEF), University of Palermo, Viale delle Scienze, Parco d'Orleans II, Palermo, Italy

2 Department of Earth and Marine Sciences (DISTeM), University of Palermo, Palermo, Italy

3 School of Pharmacy, University of Camerino, Camerino, Italy

4 School of Science and Technologies, University of Camerino, Camerino, Italy

5 Department of Chemistry, University of Rome “La Sapienza”, Rome, Italy

Key words

Prangos ferulacea, Apiaceae, coumarins, prenyl-coumarins, furano-coumarins, essential oil

received December 18, 2018

revised March 1, 2019

accepted March 5, 2019

Bibliography

DOI https://doi.org/10.1055/a-0873-8622

Published online March 20, 2019 | Planta Med 2019; 85: 815-

824 @ Georg Thieme Verlag KG Stuttgart · New York |

ISSN 0032-0943
Correspondence

Prof. Maurizio Bruno

Department of Biological, Chemical and Pharmaceutical

Sciences and Technologies (STEBICEF), University of Palermo

Viale delle Scienze Ed. 17, Parco d'Orleans II, 90128 Palermo, Italy

Phone: + 3909123897531

maurizio.bruno@unipa.it

\section{ABSTRACT}

Prangos ferulacea (L.) Lindl. (Fam. Apiaceae), an orophilous species of eastern Mediterranean and western Asia, possesses a number of biological properties that are worthy of exploitation in different fields. Phytochemical investigations revealed the presence of coumarins, prenyl-coumarins, and furanocoumarins as the main constituents of this species, as well as several flavonoids. Among prenyl-coumarins, osthol is a promising apoptotic agent quite selective toward cancer cells. In addition, the essential oils have been extensively investigated, and several chemotypes have been identified. This work reviews the literature on this species published between 1965 and 2018, describes its volatile and nonvolatile metabolites, and outlines its pharmacological effects.

\section{Introduction}

The Apiaceae family comprises a set of medicinal and aromatic plants that store important secondary metabolites in internal secretory structures known as ducts and vittae, which occur in all plant organs [1]. They have been used since ancient times in traditional medicine as well as in cooking for their bioactive compounds content, including coumarins, flavonoids, polyacetylenes, and essential oils [2]. The relatively safety of these compounds, along with the availability of the raw material from which they are obtained, make them exploitable in different fields [3]. The main examples of useful Apiaceae are anise, cumin, fennel, dill, caraway, and coriander [4]. Other Apiaceae, in particular the Cachrys group, deserve further exploration for possible use on the industrial level.
The Cachrys group (fam. Apiaceae, subfam. Apioideae) is divided into several genera: Prangos, Alocacarpum, Cachrys, Bilacunaria, Ferulago, Diplotaenia, Eriocycla, and Azilia [5].

According to the Plant List [6], there are 19 accepted Prangos species. They are mainly distributed in the eastern Mediterranean area, the Balkans, the Middle East, and western Asia and many of them are endemic in Turkey. Species of the genus Prangos found in Italy are Prangos ferulacea Lindl. and Prangos trifida (Miller) Herrnst. \& Heyn, whereas in western Europe, only P. trifida occurs [7].

Dedicated to Professor Dr. Cosimo Pizza in recognition of his important contributions to natural product research on the occasion of his 70th birthday in 2019. 
The Prangos Lindl. genus [8] consists of perennial herbaceous plants. Its stems are well branched, without coasts, at the base, with a well-developed and persistent collar of fibrous parts. Its leaves are 4-7(3)-pinnate, glabrous, with numerous thread-like, acute leaflets. The umbels are composed of numerous flowers. The bracts and bracteoles are sometimes deciduous, and the flowers are hermaphrodite and male. The goblet has more or less evident teeth. Its petals are yellow, broadly ovate, with curved peak, and homogeneous. The fruits are oblong, more or less compressed laterally, and hairless. The mericarps are smooth, free of externally marked coasts, with semielliptical or semicircular sections, with spongy mesocarp; vittae are numerous and form a continuous ring. The seeds have the endosperm convoluted on the commissural face [9].

P. ferulacea (synonyms: Cachrys alata Hoffm., C. alata M. Bieb., Cachrys ferulacea [L.] Calest., Cachrys goniocarpa Boiss., Cachrys prangoides Boiss., Laserpitium ferulaceum L., Prangos alata Grossh., Prangos biebersteinii Karjagin, Prangos carinata Griseb. ex Grecescu) [6] is an orophilous species of the eastern Mediterranean and western Asia, where it grows in arid, stony, mountain pastures, preferentially on basic soils. In Sicily, it is fairly widespread on the carbonate mountains, above 1000 m of altitude; it flowers in May to June and fruits in July to August. In the Madonie Mountains (Sicily), the species is usually consumed by grazing cattle and sheep and imparts characteristic smells and flavors to their milk, which are transmitted to the derived dairy products such as cheese and salted ricotta, very appreciated and sought after by local communities [10]. In Turkey, P. ferulacea is known as "heliz" and is used as an ingredient of the very famous cheese, "otlu", produced traditionally in eastern cities, particularly around Van province, as it provides characteristic appearance and special aroma as well as antimicrobial preservation [11]. In the central, southern, and eastern mountains of Turkey, where it is called "çaşir", the young shoots of this plant are used as a vegetable, consumed boiled, fried, and pickled [12]. In Persian folk medicine, $P$. ferulacea has been used as a carminative, emollient tonic for gastrointestinal and liver disorders, and as anti-flatulent, sedative, anti-inflammatory, anti-viral, anti-helminthic, antifungal and antibacterial agent [13]. It is locally known as "jashir" and also serves as food and yogurt seasoning [14].

This work reviews reports published between 1965 and 2018 on the volatile and nonvolatile secondary metabolites and the biological activities of $P$. ferulacea with the aim of stimulating further research that may open the way to new applications of this species.

\section{Nonvolatile Metabolites}

\section{Occurrence}

The roots from different $P$. ferulacea populations growing in Armenia, Bulgaria, Iran, Russia, Sardinia, and Turkey have been the subject of extensive phytochemical investigations ( $\bullet$ Table 1 ). They were shown to be extremely rich in coumarins, the main class of secondary metabolites detected so far. In addition, the aerial parts contain not only coumarin derivatives, but also several flavonoid glycosides and the trisaccharide umbelliferose (46) (in a Sar- dinian population) ( $\bullet$ Table 1 ). The structures of all the metabolites are depicted in $>$ Figs. 1, 2, and $\mathbf{3}$.

Coumarins are widely distributed plant metabolites. Starting from the parent structure, coumarin (1,2-benzopyrone), which was isolated around $200 \mathrm{y}$ ago, several biogenetic modifications can occur on the basic skeleton. A quite common feature is the presence of an oxygen substituent on C-7, as can be observed in all the structures reported in the present review (1-39). Oxygenation can also occur at 1 or more of the remaining positions of the coumarin skeleton. These oxygen atoms can be present as phenol $(1,3,4)$ or ethereal groups $(2,5-39)$.

Another common feature in most of the coumarin-based structures is the presence of a prenyl group, variedly oxidized, that can be linked to a carbon atom of the skeleton (4-12) or to an oxygen atom $(13,24-36,39)$. The oxidative ring closure of the prenyl group with a close oxygen results in the formation of hydroxyisopropylfuran moiety $(20-23,37,38)$. Further loss of acetone leads to a furan ring $(16-19,24-36,39)$. The biochemical activities, dietary sources and intake, and potential health risks of furanocoumarins have been recently reviewed [40]. An alternative cyclization of the C-prenyl group can afford pyrano-coumarins $(14,15)$.

\section{Biological properties of $P$. ferulacea extracts and nonvolatile metabolites}

\section{Cytotoxic activity}

The cytotoxic potential of coumarins isolated from $P$. ferulacea on PC3, SKNMC, and H1299 (p53 null) human carcinoma cell lines was evaluated. Osthol (5) was shown to be a potent cytotoxic agent against PC 3 cells $\left(\mathrm{IC}_{50}=20.1 \mu \mathrm{M}\right)$, whereas isoimperatorin (31) exhibited moderate inhibitory effects against SKNMC and PC3 cell lines ( $\mathrm{IC}_{50}=182 \mu \mathrm{M}$ and $119.4 \mu \mathrm{M}$, respectively). On the other hand, oxypeucedanin (34) and braylin (14) did not display any cytotoxic activity. Furthermore, the apoptotic properties of osthol (5) and isoimperatorin (31) were investigated, with quite interesting results. Osthol (5) induced apoptosis in PC3 and SKNMC cell lines via both mitochondrial and extrinsic pathways, whereas it induced the apoptotic cell death via a p53 independent pathway in $\mathrm{H} 1299$ cells [24]. Osthol (5) and osthol derivatives also showed growth inhibitory activity against MCF-7 and MDA-MB-231 human breast carcinoma cell lines [41]. Remarkably, osthol (5) is not toxic to normal cells (HEK-293 and Vero cell lines) $[26,41]$. Osthol (5) was also shown to have cytotoxic effects on A2780S human ovarian carcinoma cell line $\left(\mathrm{IC}_{50}=0.54 \mathrm{mM}\right)$ and isoimperatorin (31) was shown to be a nontoxic cyclooxygenase-2 inhibitor [26]. Pre-treatment with nontoxic concentrations of osthol (5) protected PC12 cells from DOX-mediated apoptosis by inhibition of ROS (radical oxygen species) production [42]. In another paper, several coumarins obtained from $P$. ferulacea root, namely osthol (5), psoralen (16), isoimperatorin (31), pranferol (27), gosferol (28), oxypeucedanin (29), oxypeucedanin hydrate (30), and oxypeucedanin methnolate (36), were reported to exhibit moderate cytotoxic and anti-HIV properties [27].

Investigations of the safety of osthol (5) have found that it is moderately toxic substance when administered i. p. in rodents. The no-observed adverse-effect level of osthol (5) for both male and female rats is considered to be less than $5 \mathrm{mg} / \mathrm{kg}$ [43]. These 
- Table 1 Occurrence of nonvolatile metabolites in different populations of $P$. ferulacea.

\begin{tabular}{|c|c|c|c|c|}
\hline Parts & Origin & Other metabolites & Coumarins & Ref. \\
\hline roots & Armenia & & pranferol (32) & [15] \\
\hline roots & Armenia & & $\begin{array}{l}\text { osthol (5), meransin (6), meransin hydrate (7), xanthotoxin (17), } \\
\text { prangeferol (marmesin) (20), isoimperatorin (31), pranferol (32), } \\
\text { oxypeucedanin (34), oxypeucedanin hydrate (35) }\end{array}$ & {$[16,17]$} \\
\hline stems & Armenia & & osthol (5), isoimperatorin (31), oxypeucedanin (34) & [16] \\
\hline roots & Armenia & & prangone (12), ferudenol (13) & [18] \\
\hline $\begin{array}{l}\text { aerial } \\
\text { parts }\end{array}$ & Azerbaijan & $\begin{array}{l}\text { quercetin 3-O- } \beta \text {-glucoside } \\
(41) \text {, isorhamnetin 3-O- } \beta \text { - } \\
\text { glucoside (42), isorhamnetin } \\
\text { 3-O-glucorhamnoside (43) }\end{array}$ & celereoside (23) & [19] \\
\hline roots & Bulgaria & & $\begin{array}{l}\text { osthol (5), psoralen (16), bergapten (18), pranchimgin (21), } \\
\text { imperatorin (24), isoimperatorin (31) }\end{array}$ & [20] \\
\hline $\begin{array}{l}\text { aerial } \\
\text { parts }\end{array}$ & Egypt & $\beta$-D-gluco- $\beta$-sitosterol & $\begin{array}{l}\text { umbelliferone (1), herniarin (2), scopoletin (3), osthenol (4), } \\
\text { osthol (5), xanthotoxin (methoxsalen) (17), imperatorin (24) }\end{array}$ & [21] \\
\hline $\begin{array}{l}\text { aerial } \\
\text { parts }\end{array}$ & Iran, Tochal & $\begin{array}{l}\text { quercetin (40), quercetin } \\
3 \text {-O-glucuronide (44) }\end{array}$ & $\begin{array}{l}\text { imperatorin (24), heraclenin (26), oxypeucedanin (34), } \\
\text { sprengelianin (38), xanthotoxin (methoxsalen) (17), oroserol (37), } \\
\text { isopimpinellin (19), prangeferol (marmesin) (20), phellopterin (27), } \\
\text { heraclenol (28), oxypeucedanin hydrate (35), [3-hydroxy-2- } \\
\text { methyl-4-(7-oxofuro[3,2 g]chromen-9-yl) oxybutan-2-yl] (Z)-2- } \\
\text { methylbut-2-enoate (29), 8-[2-(3-methylbutyroxy)-3-hydroxyl-3- } \\
\text { methylbutoxylpsoralen (30), rivulobirin A (39) }\end{array}$ & [22] \\
\hline $\begin{array}{l}\text { aerial } \\
\text { parts }\end{array}$ & Iran, West-Azerbaijan & $\begin{array}{l}\text { quercetin } 3-O-\beta \text {-glucoside } \\
\text { (41), isorhamnetin } 3-O-\beta \text { - } \\
\text { glucoside (42), caffeic acid } \\
\text { glucosyl ester (47) }\end{array}$ & imperatorin (24), ferudenol (13) & [23] \\
\hline roots & Iran & & osthol (5), braylin (14), isoimperatorin (31), oxypeucedanin (34) & {$[24,25]$} \\
\hline roots & Iran & & $\begin{array}{l}\text { osthol (5), psoralen (16), isoimperatorin (31), pranferol (32), } \\
\text { gosferol (33), oxypeucedanin (34), oxypeucedanin hydrate (35), } \\
\text { oxypeucedanin methnolate (36) }\end{array}$ & {$[26,27]$} \\
\hline $\begin{array}{l}\text { whole } \\
\text { plant }\end{array}$ & Iran & $\begin{array}{l}\text { quercetin } 3-O \text {-glucuronide } \\
\text { (44), isorhamnetin } 3-O-\beta \text { - } \\
\text { glucuronide (45) }\end{array}$ & & [28] \\
\hline roots & Italy, Sardinia & & $\begin{array}{l}\text { osthol (5), decursin (15), imperatorin (24), heraclenin ( } 26) \text {, } \\
\text { isoimperatorin (31), oxypeucedanin (34) }\end{array}$ & [29] \\
\hline seeds & Italy, Sardinia & & $\begin{array}{l}\text { osthol (5), decursin (15), imperatorin (24), heraclenin ( } 26) \text {, } \\
\text { isoimperatorin (31), oxypeucedanin (34) }\end{array}$ & [29] \\
\hline fruits & Italy, Sardinia & umbelliferose (46) & & [30] \\
\hline fruits & Italy, Sicily & & osthol (5), bergapten (18), imperatorin (24), isoimperatorin (31) & [31] \\
\hline roots & Russia, Bichenak Mt & & $\begin{array}{l}\text { osthol (5), meransin hydrate (7), isoimperatorin (31), } \\
\text { oxypeucedanin (34), oxypeucedanin hydrate (35) }\end{array}$ & [32] \\
\hline roots & Russia, Bichenak Mt & & pranferol (32) & [33] \\
\hline fruits & Russia, Bichenak Mt & & osthol (5), isoimperatorin (31), oxypeucedanin (34) & [34] \\
\hline roots & Russia, Bichenak Mt & & pranferin (9) & {$[35,36]$} \\
\hline roots & Russia, Bichenak Mt & & gosferol (33) & [37] \\
\hline roots & Russia, Nakhichevan & & $\begin{array}{l}\text { umbelliferone (1), meransin hydrate monoacetate (8), ferudiol (10), } \\
\text { 3'-O-methylferudiol (11), ferudenol (13), lindiol (22), feruliden (25) }\end{array}$ & {$[18,38]$} \\
\hline roots & Turkey & & $\begin{array}{l}\text { imperatorin (24), oxypeucedanin hydrate (35), pranchimgin (21), } \\
\text { isoimperatorin (31) }\end{array}$ & [39] \\
\hline
\end{tabular}

findings suggest that osthol (5) might prove to be useful as a therapeutic agent in carcinoma treatment mainly in phenotypic-resistant cell lines due to defect in p53 function. Randomized clinical trials are important to evaluate the safety and efficacy of osthol in patients with different types of cancers.

\section{Antioxidant and antimicrobial activities}

The methanolic extract from aerial parts of $P$. ferulacea collected in eastern Turkey was found to be a good antioxidant with $50 \%$ inhibitory concentration values at 0.242 and $0.152 \mathrm{mg} / \mathrm{mL}$ in DPPH (2,2-Diphenyl-1-picrylhydrazyl) radical scavenging and lipid per- 


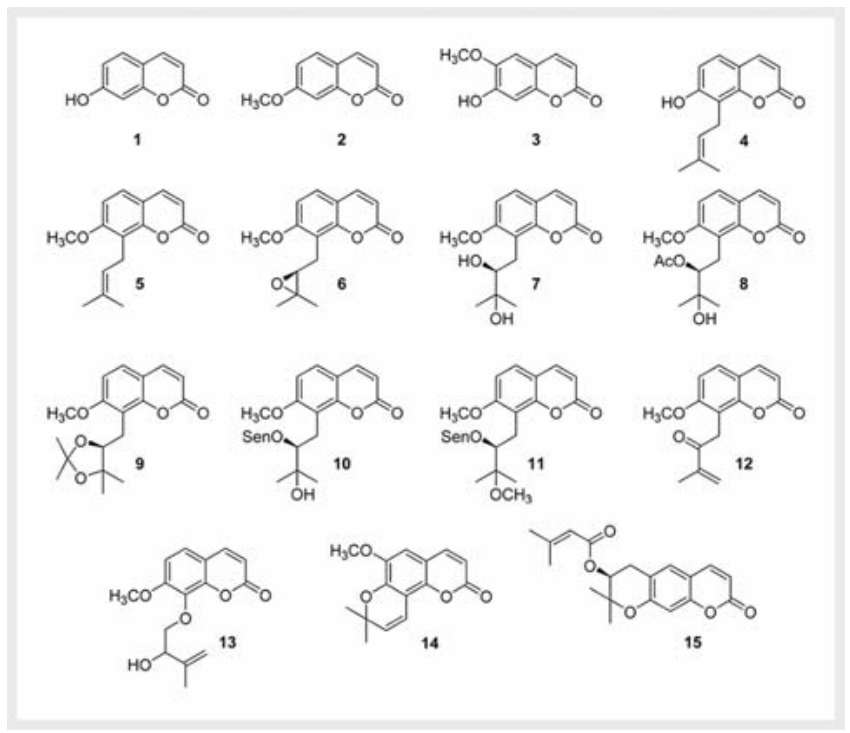

- Fig. 1 Chemical structures of coumarins of $P$. ferulacea.

oxidation inhibition assays, respectively. It was also evaluated for its effect on glutathione-S-transferase activities showing an $\mathrm{IC}_{50}$ value of $79.25 \mu \mathrm{g} / \mathrm{mL}[44,45]$.

Various solvent extracts (water, methanol, ethanol, and ethyl acetate) of different herbs, traditionally used in eastern Turkey to enhance the aromatic properties of cheese, were tested for their antioxidant properties. The methanolic extract of $P$. ferulacea showed the highest DPPH and ABTS (2,2'-Azino-bis(3-ethylbenzothiazoline-6-sulfonic acid) diammonium salt) radical-scavenging activities. Furthermore, a moderate antimicrobial activity against Enterococcus faecalis (MIC [minimal inhibitory concentration] value of $250 \mu \mathrm{g} / \mathrm{mL}$ ) was observed [11]. Quercetin glucoside (41) and isorhamnetin glucoside (42), isolated from the methanolic extract of $P$. ferulacea aerial parts collected in Eastern Azerbaijan province, Iran, exhibited strong antioxidant activity in the DPPH assay with $R C_{50}$ values of 36.2 and $64.4 \mu \mathrm{g} / \mathrm{mL}$, respectively [19]. Cytotoxic, phytotoxic, antimicrobial, and antioxidant effects of quercetin glucoside (41) isolated from aerial parts of $P$. ferulacea and characterized by HPLC were studied by MTT assay, lettuce germination assay, disk diffusion, and DPPH methods. Quercetin glucoside (41) exhibited the highest antioxidant activity in the DPPH assay with an $\mathrm{RC}_{50}$ value of $22 \mu \mathrm{g} / \mathrm{mL}$, whereas no activity against Bacillus cereus, Escherichia coli, Staphylococcus epidermidis, Pseudomonas aeruginosa, and Candida kefyr was detected [46].

The antibacterial effects of 4 extracts (ethanolic, methanolic, aqueous, and hexanic) of $P$. ferulacea against several gram-positive bacteria such as B. cereus, Bacillus subtilis, Micrococcus luteus, and Staphylococcus aureus were evaluated. The highest inhibitory effects were observed against $M$. luteus and $S$. aureus for ethanolic (16 and $16 \mathrm{~mm}$ inhibition zone diameters, respectively) and methanolic extracts (12 and $16 \mathrm{~mm}$ inhibition zone diameters, respectively) [47].

Recently, a clinical trial showed that $P$. ferulacea vaginal cream, containing its extract plus oral metronidazole, prepared in the laboratory of the School of Pharmacy of Shahid Beheshti Univer-

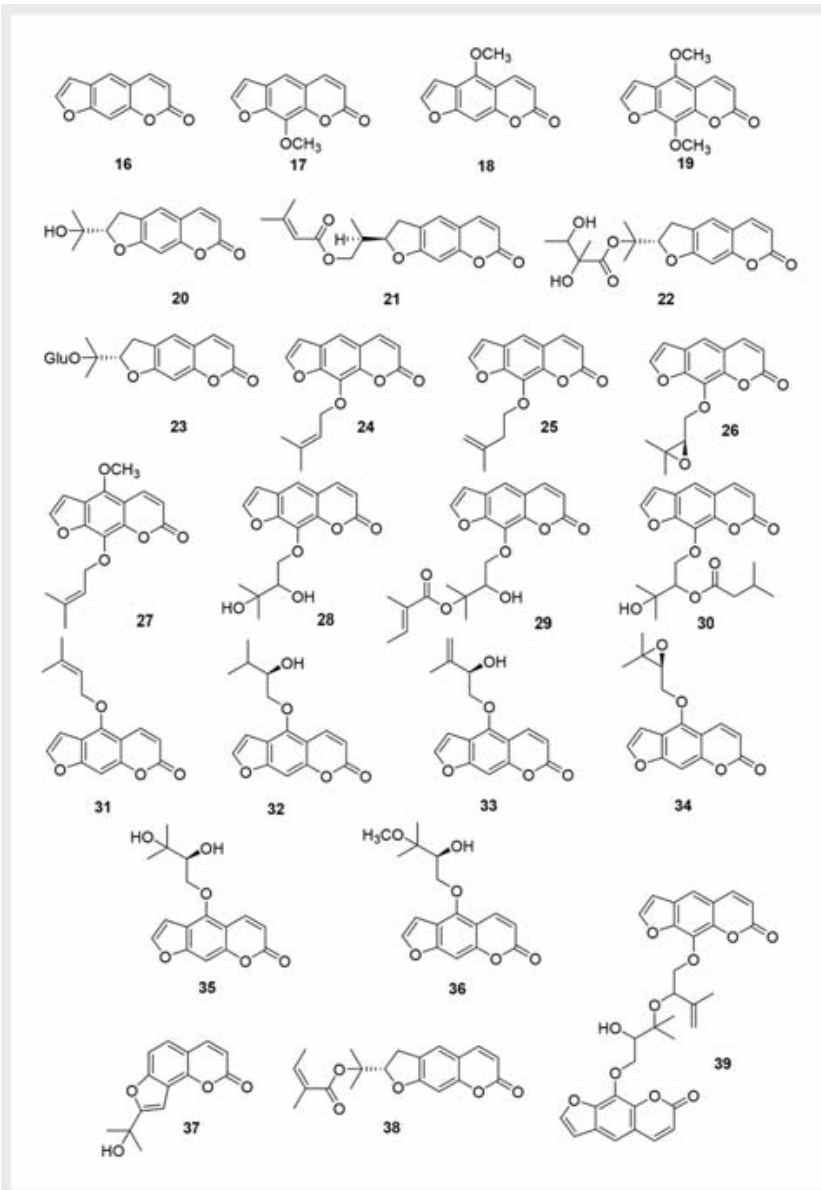

- Fig. 2 Chemical structures of furo- and dihydrofuro-coumarins of P. ferulacea.

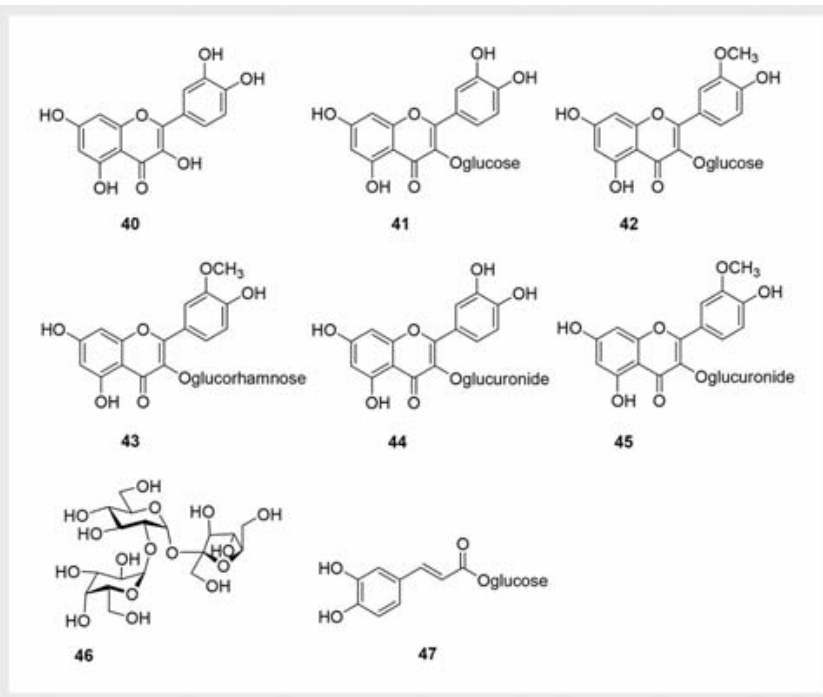

- Fig. 3 Chemical structures of other metabolites of $P$. ferulacea. 
sity of Medical Sciences, accelerated the recovery of patients with bacterial vaginosis. Thus, it can be used effectively as a complementary treatment with oral metronidazole in cases of medication resistance [48].

\section{Hypoglycemic activity}

The hypoglycemic and hypolipidemic effects of the $P$. ferulacea root hydroalcoholic extract in alloxan-induced diabetic rats were studied. A 4-wk treatment of diabetic rats with a hydroalcoholic extract of roots $(100 \mathrm{mg} / \mathrm{kg})$ caused significant decrease in blood glucose (from 383 to $309 \mathrm{mg} / \mathrm{dL}$ ), similar to the results obtained with $1 \mathrm{lU} / \mathrm{kg}$ of insulin $(298 \mathrm{mg} / \mathrm{dL})$. On the basis of these results, it was concluded that the $P$. ferulacea extract can be used in the treatment of diabetes to reduce the blood glucose and lipid profile. Furthermore, the extract was found to influence changes of aminotransferases and to prevent the histopathological changes of liver in diabetic rats $[49,50]$. Other researchers confirmed these results; in fact, a 3 -wk diet with $P$. ferulacea hydroalcoholic extract $(500 \mathrm{mg} / \mathrm{kg})$ resulted in a significant decrease in blood glucose in diabetic male Wistar rats (from 380 to $160 \mathrm{mg} / \mathrm{dL}$ ) and also in ALT (alanine aminotransferase), AST (aspartate aminotransferase), and creatinine, but no significant decrease in ALP (alkaline phosphatase), albumin, urea, and BUN (blood urea nitrogen) levels. Consequently, it may possibly serve to alleviate the liver and kidney damage caused by streptozotocin-induced diabetes mellitus [51]. These results could be ascribed to the presence in the extract of coumarins, such as umbelliferone (1), whose antihyperlipidemic and antidiabetic properties have already been proven [52].

\section{Analgesic effects}

The analgesic effects of aqueous and methanolic extracts of $P$. ferulacea on formalin-induced pain in female rats were examined. The results showed that both extracts exerted analgesic properties through peripheral and central analgesia [53].

Noteworthy antispasmodic effects of the $P$. ferulacea acetone extract and its main constituents, namely osthol (5) and prenylated coumarins, on rat ileum contraction and uterus smooth muscle motility have also been reported. The relaxation effects of osthol (5) might be mediated through $\mathrm{Ca}^{2+}$ channel blocking activity, as it inhibited the response to $\mathrm{KCl}[14,54]$.

\section{Other properties}

$P$. ferulacea is used in Iranian traditional medicine for the treatment of gastrointestinal disorders. However, it seems to exert an abortifacient effect on pregnant women. A study by Kazerooni and Mousavizadeh [55] showed that the leaf aqueous and hydroalcoholic extracts of $P$. ferulacea did not significantly increase the rate of abortion in pregnant rats. However, further investigations should be conducted to test the safety of these extracts in other animals [56].

The $n$-hexane extract was evaluated for inhibitory activity on acetylcholinesterase enzyme (AChE), a key target for the discovery of new treatments of Alzheimer's disease. This extract showed a significant AChE inhibitory activity, with $75.6 \%$ inhibition at a concentration of $50 \mu \mathrm{g} / \mathrm{mL}$. A further bio-assay-guided fractionation showed that the fraction containing imperatorin (24), oxy- peucedanin (34), oxypeucedanin hydrate (35), oroserol (37), rivulobirin A (39), quercetin (40), and quercetin 3-O-glucuronide (44) was the most active against $A C h E$, showing an $I_{50}$ value of $25.2 \mu \mathrm{g} / \mathrm{mL}$ as well as good docking scores of its constituents [22].

\section{Volatile Metabolites}

\section{Essential oils}

With regard to the composition of the essential oils obtained from different parts of $P$. ferulacea from different geographic origin, several papers have been published. Most of them refer to natural populations growing in Iran, while a few studies have been performed on those from Turkey, Greece, Montenegro, and Italy ( $\triangleright$ Table 2). The essential oil derived from whole aerial parts contains different chemotypes. Terpinolene (38.1-56.3\%) [57], $\delta$-3carene (45.9\%), limonene (55.1\%) [58] and $\beta$-pinene (43.0\%) [59] were found as the major constituents in the oils obtained from samples during the vegetative stage. $\alpha$-Pinene $(41.3 \%)$ and $\delta$-3-carene (34.6\%) [58], (E)-caryophyllene (48.2\%) [60], $\alpha$-pinene (37.1\%), and $\beta$-pinene (33.8\%) [59] were found as the most abundant volatile components in flowering aerial parts. $\alpha$-Pinene (31.7\%) and $\beta$-pinene (38.5\%) were the major components in the oil obtained from aerial parts during the fruiting stage [59]. The leaf oil was mostly characterized by linalool (36.7\%) [61], (E)- $\beta$ ocimene (13.6-28.2\%) [62,63], and $\beta$-pinene (29.6\%) [64], with minor contributions of limonene (12.2-15.2\%) and 2,3,6-trimethylbenzaldehyde (12.7\%), and $\alpha$-pinene (19.8\%) and $\delta$-3carene (11.4\%). Interestingly, a significant variation was found when the leaf oil sample obtained from the vegetative stage was compared with that from the flowering stage [65]. Indeed, the former was characterized by $\alpha$-pinene $(57.0 \%)$, whereas the latter was dominated by $(E)$-anethole $(95.5 \%)$. The oil obtained from umbels was characterized by $\alpha$-pinene (42.2\%) [66], linalool (19.0\%) and lavandulyl acetate (16.0\%) [61], and $\beta$-pinene $(20.6 \%)$ and $\delta$-3-carene $(10.4 \%)$ [64,67]. Fruit oil exhibited a different chemical profile, with $\alpha$-pinene $(18.0-26.3 \%)[66,68]$, chrysanthenyl acetate (26.5\%) [69], and $\gamma$-terpinene (27.8$30.2 \%)[70,71]$ as the major constituents. The stem oil was characterized by 1,8 -cineole (19.0\%) and $\alpha$-pinene (10.3\%) [61]. The root oil was found to be rich in $\beta$-phellandrene (11.8-32.1\%) and $\delta$-3-carene (22.5-25.8\%) [72,73] and 3,5-nonadiyne (85\%) [74]. The significant variability observed in the various studies can be mainly ascribed to differences in geographic origin (related, for example, to pedoclimatic factors), phenological stage, and genetics of the samples.

\section{Biological properties of essential oils Antioxidant and antimicrobial activities}

The essential oil obtained from the aerial parts of $P$. ferulacea growing in Semnan province, Iran (main components: $\beta$-phellandrene [20.4\%], $\alpha$-terpinolene [15.3\%], $\alpha$-pinene [11.6\%], $\delta$-3carene [11.1\%], (E)- $\beta$-ocimene [9.7\%], and $\alpha$-phellandrene [9.1\%]), showed antibacterial activity against E. coli and Staphylococcus saprophyticus, with MIC values of 3.27 and $8.19 \mu \mathrm{g} / \mathrm{mL}$, respectively [78], whereas the essential oils of fruits and flowers of plants growing in East Azerbaijan, Iran, both rich in $\alpha$-pinene and 
- Table 2 Main constituents (> 3\%) of the essential oils of Prangos ferulacea.

\begin{tabular}{|c|c|c|c|}
\hline Plant part & Origin & Compounds (\%) & Ref. \\
\hline aerial parts ${ }^{\mathrm{a}}$ & Greece, Crete & $\begin{array}{l}\gamma \text {-terpinene (27.5), } \alpha \text {-pinene (10.4), } \alpha \text {-terpinolene (9.0), (E)- } \beta \text {-ocimene (8.8), } p \text {-cymene (6.8), } \\
\text { apiole (5.5), myrcene (4.4) }\end{array}$ & [75] \\
\hline $\begin{array}{l}\text { leaves }^{\text {a }} \\
\text { (veget. stage) }\end{array}$ & Iran, E. Azerbaijan & $\begin{array}{l}\alpha \text {-pinene (57.0), 3-ethylidene-2-methyl-1-hexen-4-yne (5.3), } \beta \text {-pinene (4.5), } \\
(E) \text {-anethole (3.9), caryophyllene oxide (3.5) }\end{array}$ & {$[65]$} \\
\hline $\begin{array}{l}\text { leaves }{ }^{\text {a }} \\
\text { (flow. stage) }\end{array}$ & Iran, E. Azerbaijan & $(E)$-anethole $(95.5)$ & {$[65]$} \\
\hline fruits $^{\mathrm{a}}$ & Iran, E. Azerbaijan & $\alpha$-pinene (63.1), cis-ocimene (9.7), $\beta$-pinene (8.3), myrcene (4.8) & {$[66]$} \\
\hline umbels $^{\mathrm{a}}$ & Iran, E. Azerbaijan & $\alpha$-pinene (42.2), cis-ocimene (36.3), myrcene (5.0), $\beta$-phellandrene (3.3) & {$[66]$} \\
\hline roots $^{\mathrm{a}}$ & Iran, W. Azerbaijan & $\beta$-phellandrene (32.1), $m$-tolualdehyde (26.2), $\delta$-3-carene (25.8), $\alpha$-pinene (4.7) & {$[72]$} \\
\hline aerial parts & Iran, Azerbaijan & $\beta$-pinene (43.1), $\alpha$-pinene (22.1), $\delta$-3-carene (16.9), $\alpha$-terpinolene (3.9) & {$[23]$} \\
\hline leaves ${ }^{\mathrm{a}}$ & Iran, Esfahan & linalool (36.7), caryophyllene oxide (16.3), $\alpha$-pinene (12.1), 1,8-cineole (8.9) & {$[61]$} \\
\hline stems $s^{\mathrm{a}}$ & Iran, Esfahan & 1,8-cineole (19.0), $\alpha$-pinene (10.3), caryophyllene oxide (4.2), linalool (3.7) & {$[61]$} \\
\hline flowers $^{\mathrm{a}}$ & Iran, Esfahan & $\begin{array}{l}\text { linalool (19.0), lavandulyl acetate (16.0), 1,8-cineole (14.5), } \alpha \text {-pinene (12.4), geranyl } \\
\text { isobutyrate (12.2), } \alpha \text {-campholenal (7.0), } \alpha \text {-cadinol (6.4) }\end{array}$ & {$[61]$} \\
\hline leaves ${ }^{a}$ & Iran, Fars & $\begin{array}{l}\text { (E)- } \beta \text {-ocimene (13.6), 2,3,6-trimethylbenzaldehyde (12.7), } p \text {-cymene (9.7), terpinolene (8.3), } \\
\text { (E)-caryophyllene (5.4), } \beta \text {-elemene (5.3), germacrene } D(5.0), \alpha \text {-bisabolol (4.9), limonene } \\
\text { (4.5), kessane (3.4), } \gamma \text {-terpinene (3.4), } \alpha \text {-pinene (3.0) }\end{array}$ & {$[62]$} \\
\hline leaves ${ }^{\mathrm{b}}$ & Iran, Fars & $\begin{array}{l}\text { (E)- } \beta \text {-ocimene (23.6), limonene (13.3), p-cymene (12.2), 2,3,6-trimethylbenzaldehyde (7.4), } \\
\text { terpinolene (6.7), } \alpha \text {-pinene (3.9), (E)-caryophyllene (3.1) }\end{array}$ & {$[63]$} \\
\hline leaves ${ }^{a}$ & Iran, Fars & $\begin{array}{l}\text { (E)- } \beta \text {-ocimene (28.2), limonene (12.2), terpinolene (8.7), } p \text {-cymene (7.1), 2,3,6-trimethyl- } \\
\text { benzaldehyde (7.0), germacrene D (5.0), (E)-caryophyllene (3.9), } \alpha \text {-pinene (3.7), } \beta \text {-elemene } \\
\text { (3.5), } \gamma \text {-terpinene (3.3) }\end{array}$ & {$[63]$} \\
\hline leaves ${ }^{c}$ & Iran, Fars & $\begin{array}{l}\text { (E)- } \beta \text {-ocimene (22.1), limonene (15.2), 2,3,6-trimethylbenzaldehyde (8.6), } p \text {-cymene (7.6), } \\
\text { terpinolene (6.6), (E)-caryophyllene (4.4), } \beta \text {-elemene (3.7), } \alpha \text {-pinene (3.2), } \alpha \text {-bisabolol (3.0) }\end{array}$ & {$[63]$} \\
\hline $\begin{array}{l}\text { aerial parts }{ }^{\mathrm{a}} \\
\text { (grow. stage), fresh }\end{array}$ & Iran, North Fars & terpinolene (56.3), (E)-caryophyllene (4.7), bornyl acetate (3.0) & [57] \\
\hline $\begin{array}{l}\text { aerial parts } \\
\text { (grow. stage), dry }\end{array}$ & Iran, North Fars & terpinolene (38.1), (E)-caryophyllene (3.6), bornyl acetate (1.8) & [57] \\
\hline $\begin{array}{l}\text { aerial parts }{ }^{\mathrm{a}} \\
\text { (veget. stage), fresh }\end{array}$ & Iran, North Fars & $\delta$-3-carene (45.9), indole (11.6), terpinolene (9.6), p-cymen-8-ol (6.2), n-pentadecanol (5.5) & {$[58]$} \\
\hline $\begin{array}{l}\text { aerial parts }{ }^{\mathrm{a}} \\
\text { (veget. stage), dry }\end{array}$ & Iran, North Fars & limonene (55.1), $\gamma$-terpinene (10.7), bornyl acetate (8.5) & {$[58]$} \\
\hline $\begin{array}{l}\text { aerial parts }{ }^{\mathrm{a}} \\
\text { (flow. stage), fresh }\end{array}$ & Iran, North Fars & $\begin{array}{l}\alpha \text {-pinene (41.3), } \delta \text {-3-carene (34.6), limonene (14.6), } \beta \text {-pinene (9.5), terpinolene (8.1), } \\
\text { myrcene (7.4), sabinene (4.7), } \alpha \text {-phellandrene (4.1) }\end{array}$ & {$[58]$} \\
\hline $\begin{array}{l}\text { aerial parts }{ }^{\mathrm{a}} \\
\text { (flow. stage), dry }\end{array}$ & Iran, North Fars & $\alpha$-pinene (24.2), $\delta$-3-carene (7.7), $\beta$-pinene (8.6), terpinolene (3.8), $\beta$-phellandrene (4.4) & {$[58]$} \\
\hline $\begin{array}{l}\text { aerial parts }{ }^{\mathrm{a}} \\
\text { (flow. stage) }\end{array}$ & Iran, Kermanshah & (E)-caryophyllene (48.2), $\alpha$-humulene (10.2), spathulenol (9.3), linalool (3.5), $\delta$-3-carene (3.4) & {$[58]$} \\
\hline leaves $^{\mathrm{a}}$ & Iran, Kurdistan & $\begin{array}{l}\beta \text {-pinene (29.6), } \alpha \text {-pinene (19.8), } \delta \text {-3-carene (11.4), } \beta \text {-phellandrene (11.1), } \beta \text {-caryophyllene } \\
\text { (3.7) }\end{array}$ & {$[67]$} \\
\hline flowers $^{a}$ & Iran, Kordestan & $\begin{array}{l}\beta \text {-pinene (20.6), } \delta \text {-3-carene (10.4), } \alpha \text {-pinene (8.8), } \beta \text {-phellandrene (8.1), germacrene D (5.8), } \\
\alpha \text {-humulene (5.3), } p \text {-cymene (3.8), } \delta \text {-cadinene (3.3) }\end{array}$ & {$[67]$} \\
\hline leaves ${ }^{a}$ & Iran, Khorrasan & $\begin{array}{l}\beta \text {-pinene (29.6), } \alpha \text {-pinene (19.8), } \delta \text {-3-carene (11.4), } \beta \text {-phellandrene (11.1), (E)-caryophyllene } \\
(3.7)\end{array}$ & {$[64]$} \\
\hline flowers $^{a}$ & Iran, Khorrasan & $\begin{array}{l}\beta \text {-pinene (20.6), } \delta \text {-3-carene (10.4), } \alpha \text {-pinene (8.8), } \beta \text {-phellandrene (8.1), germacrene } \mathrm{D}(5.3) \text {, } \\
p \text {-cymene (3.8), } \delta \text {-cadinene (3.3) }\end{array}$ & {$[64]$} \\
\hline roots $^{\mathrm{a}}$ & $\begin{array}{l}\text { Iran, Kohgiluyeh- } \\
\text { Boirahmad }\end{array}$ & $\begin{array}{l}\delta \text {-3-carene (22.5), } \beta \text {-phellandrene (11.8), } \alpha \text {-pinene (8.6), terpinolene (7.2), } p \text {-cymene (6.3), } \\
\alpha \text {-phellandrene (6.2), myrcene (4.5), sabinene (3.6), bornyl acetate (3.2), } \gamma \text {-terpinene (3.0) }\end{array}$ & {$[73]$} \\
\hline aerial parts ${ }^{a}$ & Iran, Lorestan & $\begin{array}{l}\alpha \text {-pinene (36.6), } \beta \text {-pinene (31.9), } \beta \text {-phellandrene (11.7), terpinolene (6.9), } \alpha \text {-phellandrene } \\
\text { (3.9), (E)-caryophyllene (3.1) }\end{array}$ & {$[76]$} \\
\hline $\begin{array}{l}\text { aerial parts }{ }^{\mathrm{a}} \\
\text { (pre-flow. stage) }\end{array}$ & Iran, Lorestan & $\beta$-pinene (43.0), $\alpha$-pinene (40.0), $\beta$-phellandrene (6.5), $\alpha$-terpinene (5.1) & {$[59]$} \\
\hline
\end{tabular}


- Table 2 Continued

\begin{tabular}{|c|c|c|c|}
\hline Plant part & Origin & Compounds (\%) & Ref. \\
\hline $\begin{array}{l}\text { aerial parts } \\
\text { (flow. stage) }\end{array}$ & Iran, Lorestan & $\begin{array}{l}\alpha \text {-pinene (37.1), } \beta \text {-pinene (33.8), } \delta \text {-3-carene (6.7), } \alpha \text {-terpinene (6.5), } \beta \text {-phellandrene (5.6), } \\
\text { terpinolene (4.9) }\end{array}$ & [59] \\
\hline $\begin{array}{l}\text { aerial parts }{ }^{\mathrm{a}} \\
\text { (fruit. stage) }\end{array}$ & Iran, Lorestan & $\begin{array}{l}\alpha \text {-pinene (31.7), } \beta \text {-pinene (38.5), } \beta \text {-phellandrene (10.3), terpinolene (5.1), } \alpha \text {-terpinene (4.9), } \\
\text { p-cymene (3.2) }\end{array}$ & [59] \\
\hline aerial parts ${ }^{\mathrm{a}}$ & Iran, Sanandaj & $\begin{array}{l}\beta \text {-pinene (22.9), } \delta \text {-3-carene (16.0), } \alpha \text {-pinene (12.6), epi- } \alpha \text {-bisabolol (7.7), terpinolene (3.5), } \\
\text { limonene (3.1) }\end{array}$ & [77] \\
\hline aerial parts as & Iran, Semnan & $\begin{array}{l}\beta \text {-phellandrene (20.4), } \alpha \text {-terpinolene (15.3), } \alpha \text {-pinene (11.6), } \delta \text {-3-carene (11.1), (E)- } \beta \text { - } \\
\text { ocimene (9.7), } \alpha \text {-phellandrene (9.1), myrcene (4.5), sabinene (4.4), } \gamma \text {-terpinene (3.4) }\end{array}$ & [78] \\
\hline fruits ${ }^{a}$ & Iran, Tehran & $\begin{array}{l}\text { chrysanthenyl acetate (26.5), limonene (19.6), } \alpha \text {-pinene (19.5), } \delta \text {-3-carene (6.6), } \\
\text { mesitaldehyde (6.1), germacrene B (3.5) }\end{array}$ & [69] \\
\hline fruits ${ }^{a}$ & Italy, Sardinia & $\begin{array}{l}\alpha \text {-pinene (18.2), sabinene (15.9), limonene (15.1), cis-chrysanthenyl acetate (14.5), } \\
\text { 2,3,4-trimethyl benzaldehyde (13.0), } \gamma \text {-terpinene (3.3), p-cymene (3.0) }\end{array}$ & [68] \\
\hline fruits $^{\mathrm{a}}$ & Italy, Umbria & $\begin{array}{l}\gamma \text {-terpinene (27.8), (Z)- } \beta \text {-ocimene (26.8), terpinen-4-ol (12.2), } p \text {-cymene (6.9), } \alpha \text {-pinene (4.1), } \\
\beta \text {-humulene (3.5) }\end{array}$ & [70] \\
\hline roots $^{\mathrm{a}}$ & Montenegro & 3,5-nonadiyne (85\%) & [74] \\
\hline aerial parts ${ }^{d}$ & Turkey, market & $\beta$-phellandrene (22.3), $\alpha$-pinene (16.2), $p$-cymene (11.2), $\beta$-myrcene (7.2), indene (6.4) & [11] \\
\hline aerial parts ${ }^{\mathrm{a}}$ & $\begin{array}{l}\text { Turkey, } \\
\text { East Anatolia }\end{array}$ & $\begin{array}{l}\text { 2,3,6-trimethylbenzaldehyde (66.6), chrysanthenyl acetate (15.1), (E)- } \beta \text {-ocimene (3.8), } \\
\text { p-mentha-1,5-dien-8-ol (3.6) }\end{array}$ & [79] \\
\hline fruits $^{\mathrm{a}}$ & Turkey, Gavur Mt. & $\begin{array}{l}\gamma \text {-terpinene (30.2), } \alpha \text {-pinene (16.7), p-cymene (9.8), (E)- } \beta \text {-ocimene (7.7), (Z)- } \beta \text {-ocimene (7.1), } \\
\text { germacrene } B(6.6)\end{array}$ & [71] \\
\hline
\end{tabular}

cis-ocimene, displayed antibacterial effects against $B$. cereus (15 mm of inhibition zone diameter) $[65,80]$.

It was found that the essential oil from leaves of $P$. ferulacea growing in Esfahan, Iran, rich in linalool (36.7\%), caryophyllene oxide (16.3\%), $\alpha$-pinene (12.1\%), and 1,8-cineole (9.8\%), exhibited particularly strong antibacterial activity, especially against Gram-positive organisms with MIC values of $0.0625,0.25,0.50$, and $1.00 \mathrm{ppm}$ on P. aeruginosa, S. epidermidis, S. aureus and B. cereus, respectively [61]. Also, the oil from the fruits collected near Teheran, Iran, whose main components were chrysanthenyl acetate $(26.53 \%)$, limonene (19.59\%), and $\alpha$-pinene (19.50\%) presented a good activity against $S$. aureus, S. epidermis, and E. coli, producing inhibition zone diameters of 14,13 , and $12 \mathrm{~mm}$, respectively [69].

The essential oil of the aerial parts of $P$. ferulacea collected in the Broujerd mountains of Lorestan province, Iran, showed good antibacterial activity against several Gram-positive and Gramnegative bacteria, especially S. aureus. The inhibition of bacterial growth was attributed to the large content of monoterpenes such as $\alpha$-pinene (36.6\%) and $\beta$-pinene (31.1\%) [76].

The essential oil from the flowering aerial parts of $P$. ferulacea collected in East Azerbaijan, Iran, characterized by a large content of $(E)$-anethole, exhibited significant phytotoxic activity $\left(\mathrm{IC}_{50}=\right.$ $244.19 \mu \mathrm{g} / \mathrm{mL})$ on lettuce and fungitoxic effects $(0.01 \mathrm{mg} / \mathrm{mL})$ against Sclerotinia sclerotiorum [65].

It was seen that ultrasonic pre-treatment of sample had no adverse effects on the biological properties of $P$. ferulacea essential oils and particularly improved the antioxidant activity [63].

The roots of $P$. ferulacea are traditionally used as an effective wound healing agent especially for pus-filled wounds both in hu- man and livestock in the northwest of Iran. The antimicrobial properties of the root essential oil (major constituents: $\beta$-phellandrene [32.1\%], $m$-tolualdehyde [26.2\%], and $\delta$-3-carene [25.8\%]) were evaluated against Staphylococcus aureus, S. epidermidis, Escherichia coli, Pseudomonas aeruginosa, Salmonella paratyphi and Candida albicans using the agar dilution method. Very good growth inhibition of S. aureus and $P$. aeruginosa with a MIC value of $20 \mu \mathrm{g} / \mathrm{mL}$, for both pathogens, was shown. In addition, the oil, at concentrations of 4 and $16 \mu \mathrm{g} / \mathrm{mL}$, significantly enhanced the migration rate of $\mathrm{L} 929$ cells (63\% and $87 \%$, respectively, after $2 \mathrm{~d}$ ), with a significant increase of collagen production [72].

\section{Other properties}

3,5-Nonadiyne, isolated from the root essential oil of $P$. ferulacea collected in Montenegro, selectively inhibited the endogenous nitric oxide release in rat peritoneal macrophages $\left(\mathrm{IC}_{50}=6.7 \mu \mathrm{M}\right)$ without inhibiting T cell proliferation [74].

Essential oil obtained from P. ferulacea, containing mainly 2,3,6-trimethylbenzaldehyde (66.6\%) and chrysanthenyl acetate (15.1\%), was tested on different stages of Ephestia kuehniella Zeller (Lepidoptera: Pyralidae) and against the egg parasite Trichogramma embryophagum Hartig (Hymenoptera: Trichogrammatidae). The essential oil was toxic to the adult stages of both pests with $100 \%$ mortality obtained after $24 \mathrm{~h}$ at 1.0 and $0.25 \mu \mathrm{L} /$ $\mathrm{L}$ air, respectively. The $\mathrm{LC}_{50}$ and $\mathrm{LC}_{99}$ values of the essential oil against the egg stages of E. kuehniella and T. embryophagum were 320.372-486.839 and 2.121-5.662 $\mu \mathrm{L} / \mathrm{L}$ air, respectively. The results of this study indicated that essential oil of $P$. ferulacea should be used as a control agent against these pests for integrated pest management programs [79]. 


\section{Conclusions and Perspectives}

This review summarized the main phytochemicals and biological properties of $P$. ferulacea, a species traditionally used in different countries for its antispasmodic, sedative, analgesic, anti-inflammatory, antiseptic, anti-viral, and antimicrobial properties. In several cases, scientific evidence has supported and validated its traditional uses. The most investigated characteristic of this species has been its antimicrobial activity, and both extracts and essential oils have been shown to possess promising effects, thus confirming the ethno-traditional uses. Coumarins are the main class of constituents isolated to date, although a few flavonoids have also been detected. These secondary metabolites, including mainly prenyl-coumarins and furano-coumarins, showed notable cytotoxic activity that is worthy of further investigation. Despite the large number of investigations reported, other studies should be carried out in order to increase our knowledge about this species. Most of the phytochemical studies examined the less polar fractions; consequently, a complete metabolic profile that also includes polar compounds is lacking. Furthermore, the biological activities of the extracts, essential oils, and pure compounds were mainly investigated using in vitro tests. Given that the potential health risks of $P$. ferulacea-derived products have not been investigated in depth, more detailed studies will be needed before they can be used for future pharmacological and commercial purposes.

\section{Acknowledgements}

This work was supported by grant from MIUR-ITALY PRIN 2015

(Project N. 2015MSCKCE_003). Authors also wish to thank Sheila Beatty for English editing.

\section{Conflict of Interest}

The authors declare no conflicts of interest.

\section{References}

[1] Maggi F, Papa F, Giuliani C, Maleci Bini L, Venditti A, Bianco A, Nicoletti M, lannarelli R, Caprioli G, Sagratini G, Cortese M, Ricciutelli M, Vittori S. Essential oil chemotypification and secretory structures of the neglected vegetable Smyrnium olusatrum L. (Apiaceae) growing in central Italy. Flavour Fragr ] 2015; 30: 139-159

[2] Ekiert H. Medicinal plant biotechnology: the Apiaceae family as the example of rapid development. Pharmazie 2000; 55: 561-567

[3] Sayed-Ahmad B, Talou T, Saad Z, Hijazi A, Merah O. The Apiaceae: ethnomedicinal family as source for industrial uses. Ind Crops Prod 2017; 109: 661-671

[4] Benelli G, Pavela R, Petrelli R, Cappellacci L, Canale A, Senthil-Nathan S, Maggi F. Not just popular spices! Essential oils from Cuminum cyminum and Pimpinella anisum are toxic to insect pests and vectors without affecting non-target invertebrates. Ind Crops Prod 2018; 124: 236-243

[5] Ajani Y, Ajani A, Cordes JM, Watson MF, Downie SR. Phylogenetic analysis of nrDNA ITS reveals relationships within five groups of Iranian Apiaceae sub family Apioideae. Taxon 2008; 57: 383-401

[6] Royal Botanic Gardens, Kew. The Plant List. Available at www. theplantlist.org. Accessed March 12, 2019
[7] Euro+Med PlantBase. The Euro+Med PlantBase - The information resource for Euro-Mediterranean plant diversity. Available at http://ww2. bgbm.org/EuroPlusMed/query.asp. Accessed March 12, 2019

[8] Lindley J. Some account of the Prangos Hay Plant of Northern India. Quart J Sc Lit Arts 1825; 19: 7

[9] Jury SL. Cachrys L. e Prangos Lindl. In: Castroviejo Vol. 10, Iberian Flora: Vascular plants of the Iberian Peninsula and Balearic Islands; 1986: 151-155

[10] Di Martino A, Raimondo FA. Distribuzione es ecologia di Cachrys ferulacea (L.) Calestani interessante foraggera dei pascoli alto montani della Sicilia. Boll Stud Inform Bot Giardin Colon 1974; 26: 116-129

[11] Dagdelen S, Bilenler T, Durmaz G, Gokbulut I, Hayaloglu AA, Karabulut I. Volatile composition, antioxidant and antimicrobial activities of herbal plants used in the manufacture of Van Herby (OTLU) cheese. J Food Process Pres 2014; 38: 1716-1725

[12] Özcan MM, Dursun N, Arslan D. Some nutritional properties of Prangos ferulacea (L.) Lindl and Rheum ribes L. stems growing wild in Turkey. Int J Food Sci Nutr 2007; 58: 162-167

[13] Kafash-Farkhad N, Asadi-Samani M, Khaledifar B. A review on secondary metabolites and pharmacological effects of Prangos ferulacea (L.) Lindl. Life Sci J 2013; 10: 360-367

[14] Sadraei H, Shokoohinia Y, Sajjadi SE, Mozafari M. 2013. Antispasmodic effects of Prangos ferulacea acetone extract and its main component osthole on ileum contraction. Res Pharm Sci 2012; 8: 137-144

[15] Abyshev AZ. Pranferol from the roots of Prangos ferulacea. Khim Prir Soedin 1969; 5: 3-5

[16] Abyshev AZ. Coumarins and furocoumarins from the stems and roots of Prangos ferulacea indigenous to Armenia. Rastitel'nye Resursy 1969; 5 : 269-271

[17] Abyshev AZ, Denisenko PP. The structure of prangeferol. Khim Prir Soedin 1972; 8: 114

[18] Abyshev AZ. Structure of some components from of the roots of Prangos ferulacea. Khim Prir Soedin 1974; 10: 568-574

[19] Razavi SM. Phenolic compounds from the aerial parts of Prangos ferulaceae, with antioxidant activity. Eurasia J Biosci 2012; 91-96

[20] Bubeva-Ivanova L, Zheleva A, Mitrev A, Mincheva V, Savchev P. Natural coumarins. VI. Coumarin contents of Prangos ferulacea. Farmatsiia (Sofia) 1973; 23: 36-42

[21] Tawaha K, Al-Montaseb S, Al-Kalil S. Coumarins from the aerial parts of Prangos ferulacea. Alex J Pharm Sci 2001; 15: 89-91

[22] Abbas-Mohammadi M, Moridi Farimani M, Salehi P, Nejad Ebrahimi S, Sonboli A, Kelso C, Skropeta D. Acetylcholinesterase-inhibitory activity of Iranian plants: combined HPLC/bioassay-guided fractionation, molecular networking and docking strategies for the dereplication of active compounds. J Pharm Biomed Anal 2018; 158: 471-479

[23] Delnavazi MR, Soleimani M, Hadjiakhoondi A, Yassa N. Isolation of phenolic derivatives and essential oil analysis of Prangos ferulacea (L.) Lindl. aerial parts. Iran J Pharm Res 2017; 16: 207-215

[24] Shokoohinia Y, Hosseinzadeh L, Alipour M, Mostafaie A, MohammadiMotlagh HR. Comparative evaluation of cytotoxic and apoptogenic effects of several coumarins on human cancer cell lines: osthole induces apoptosis in p53-deficient H1299 cells. Adv Pharmacol Sci 2014; 2014: 847574

[25] Gholivand MB, Yamini Y, Dayeni M, Shokoohinia Y. The influence of the extraction mode on three coumarin compounds yield from Prangos ferulacea (L.) Lindl roots. J Iran Chem Soc 2015; 12: 707-714

[26] Shokoohinia Y, Sajjadi SE, Gholamzadeh S, Fattahi A, Behbahani M. Antiviral and cytotoxic evaluation of coumarins from Prangos ferulacea. Pharm Biol 2014; 52: 1543-1549

[27] Sajjadi SE, Shokoohinia Y, Gholamzadeh S, Behbahani M, Fattahi A. Antiviral evaluation of coumarins from Prangos ferulacea L. (Lindl). Res Pharm Sci 2012; 7: S783 
[28] Mouri C, Mozaffarian V, Zhang X, Laursen R. Characterization of flavonols in plants used for textile dyeing and the significance of flavonol conjugates. Dyes Pigm 2014; 100: 135-141

[29] Pistelli L, Catalano S, Manunta A, Marsili A. Coumarins from Cachrys ferulacea collected in Sardinia. Planta Med 1989; 55: 203

[30] Pistelli L, Marsili A, Morelli I, Barili PL, Pizza C. Umbelliferose from Cachrys ferulacea seeds: determination of the sugar sequence by NMR 2DCOLOC technique. Planta Med 1990; 56: 230-231

[31] Camarda L, Mazzola P, Sprio V. Coumarins from the fruits of Cachrys ferulacea. J Nat Prod 1987; 50: 310

[32] Kuznetsova GA, Abyshev AZ. Natural (-)-7-methoxy-8-( $\beta, \gamma$-dihydroxyisopentyl)coumarin. Khim Prir Soedin 1965; 1: 283-288

[33] Kuznetsova GA, Abyshev AZ, Perel'son ME, Sheinker YN, Pek GY. New coumarin, pranferol, from the roots of Prangos ferulacea. Khim Prir Soedin 1966; 2: 310-315

[34] Abyshev AZ. Coumarins from the fruits of Prangos ferulacea. Khim Prir Soedin 1968; 4: 130-131

[35] Abyshev AZ, Denisenko PP, Kostyuchenko NP, Anisimova OS, Ermakov AI, Sheinker YN. Pranferin, a new coumarin from the roots of Prangos ferulaceae. Khim Prir Soedin 1970; 6: 675-680

[36] Nikonov GK, Saidkhodzhaev Al. Structure of pranferin, a new coumarin from the roots of Prangos ferulaceae. Khim Prir Soedin 1971; 7: 255-257

[37] Abyshev AZ, Denisenko PP, Kostyuchenko NP, Ermakov Al, Sheinker YN. Gosferol, a new furocoumarin from the roots of Prangos ferulacea. Khim Prir Soedin 1972; 8: 49-54

[38] Abyshev AZ, Denisenko PP, Kostyuchenko NP, Ermakov AI, Sheinker YN. Natural acetate of meranzin hydrate, a new component of the roots of Prangos ferulacea. Khim Prir Soedin 1972; 8: 608-612

[39] Eshbakova KA, Saidkhodzhaev Al, Baser KHB, Duman H, Vdovin AD, Abdullaev ND. Furocoumarins from Prangos ferulacea. Chem Nat Comp 2006; 42: 102-103

[40] Melough MM, Cho E, Chun OK. Furocoumarins: a review of biochemical activities, dietary sources and intake, and potential health risks. Food Chem Toxicol 2018; 113: 99-107

[41] You L, An R, Wang X, Li Y. Discovery of novel osthole derivatives as potential anti-breast cancer treatment. Bioorg Med Chem Lett 2010; 20: 7426-7428

[42] Shokoohinia Y, Hosseinzadeh L, Moieni-Arya M, Mostafaie A, Mohammadi-Motlagh HR. Osthole attenuates doxorubicin-induced apoptosis in PC12 cells through inhibition of mitochondrial dysfunction and ROS production. Biomed Res Int 2014; 2014: 156848

[43] Shokoohinia Y, Bazargan S, Miraghaee S, Javadirad E, Hosseinzadeh L. Safety assessment of osthole isolated from Prangos ferulacea: acute and subchronic toxicities and modulation of cytochrome P450. Jundishapur J Nat Pharm Prod 2017; 12: e63764

[44] Mavi A, Terzi Z, Ozgen U, Yildirim A, Coskun M. Antioxidant properties of some medicinal plants: Prangos ferulacea (Apiaceae), Sedum sempervivoides (Crassulaceae), Malva neglecta (Malvaceae), Cruciata taurica (Rubiaceae), Rosa pimpinellifolia (Rosaceae), Galium verum subsp. verum (Rubiaceae), Urtica dioica (Urticaceae). Biol Pharm Bull 2004; 27: 702-705

[45] Coruh N, Sagdicoglu CAG, Oezgoekce F. Antioxidant properties of Prangos ferulacea (L.) Lindl., Chaerophyllum macropodum Boiss. and Heracleum persicum Desf. from Apiaceae family used as food in Eastern Anatolia and their inhibitory effects on glutathione-S-transferase. Food Chem 2007; 100: 1237-1242

[46] Razavi SM, Zahri S, Zarrini G, Nazemiyeh H, Mohammadi S. Biological activity of quercetin-3-O-glucoside, a known plant flavonoid. Russ J Bioorg Chem 2009; 35: 376-378

[47] Durmaz H, Sagun E, Tarakci Z, Ozgokce F. Antibacterial activities of Allium vineale, Chaerophyllum macropodum and Prangos ferulacea Afr. J Biotechnol 2006; 5: 11795-11798
[48] Azadpour Motlagh A, Dolatian M, Mojab F, Nasiri M, Ezatpour B, Sahranavard Y, Shakiba H, Rahimy B, Ghanati K. The effect of Prangos ferulacea vaginal cream on accelerating the recovery of bacterial vaginosis: a randomized controlled clinical trial. Int ] Community Based Nurs Midwifery 2018; 6: 101-110

[49] Kaffash Farkhad N, Farokhi F, Soltani Band K, Tukmacki A. Hydro-alcoholic extract of the root of Prangos ferulacea (L.) Lindl can improve serum glucose and lipids in alloxan-induced diabetic rats. Avicenna J Phytomed 2012; 2: 179-187

[50] Farokhi F, Kaffash Farkhad N, Soltani Band K, Togmechi A. Preventive effects of Prangos ferulacea (L.) Lindle on liver damage of diabetic rats induced by alloxan. Avicenna J Phytomed 2012; 2: 63-71

[51] Mokhtari M, Mohammadi ]. The effect of hydroalcoholic extracts of Prangos ferulacea on blood factors of kidney and liver functions in diabetic male wistar rats. Galen Med J 2012; 2: 174-180

[52] Ramesh B, Pugalendi K. Antihyperlipidemic and antidiabetic effects of umbelliferone in streptozotocin diabetic rats. Yale J Biol Med 2005; 78: 189-196

[53] Emamghoreishi M, Taghavi A, Javidnia K. The effect of aqueous and methanolic extracts of Prangos ferulacea on formalin-induced pain in mice. Journal of Jahrom University of Medical Sciences 2012; 9: 1-6

[54] Sadraei H, Shokoohinia Y, Sajjadi SE, Ghadirian B. Antispasmodic effect of osthole and Prangos ferulacea extract on rat uterus smooth muscle motility. Res Pharm Sci 2012; 7: 141-149

[55] Kazerooni T, Mousavizadeh K. Effect of Prangos ferulacea on abortion on pregnant rats. Fertil Steril 2005; 84: 168-169

[56] Kazerooni T, Mousavizadeh K, Abdollahee A, Sarkarian M, Sattar A. Abortifacient effect of Prangos ferulacea on pregnant rats. Contraception 2006; 73: 554-556

[57] Safaeian R, Amin G, Azarnivand H. Study of chemical compositions of the essential oils of aerial parts of Prangos ferulacea (L.) lindly in growing stage in the north of Fars province. Acta Hortic 2012; 964: 71-76

[58] Safaeian R, Amin G, Azarnivand H. Phytochemistry of Prangos ferulacea (L.) Lindl. in one of the habitats of Zagros Mountain. Ecopersia 2013; 1: 63-74

[59] Amiri H. Essential oil variation of Prangos ferulacea Lindl. in different stage of plant growth. Iran J Med Arom Plants 2007; 23: 121-127

[60] Mohebi Z, Heshmati GA, Sefidkon F, Zare Chahouki MA. The influence of plant growth stage, individuals of species, and extraction methods on the essential oil content and the chemical composition of Prangos ferulacea (L.) Lindl. Appl Ecol Env Res 2017; 15: 1765-1776

[61] Akbari MT, Esmaeili A, Zarea AH, Saad N, Bagheri F. Chemical composition and antibacterial activity of essential oil from leaves, stems and flowers of Prangos ferulacea (L.) Lindl. grown in Iran. Bulg Chem Commun 2010; 42: 36-39

[62] Seidi Damyeh M, Niakousari M. Impact of ohmic-assisted hydrodistillation on kinetics data, physicochemical and biological properties of Prangos ferulacea Lindle. essential oil: comparison with conventional hydrodistillation. Innov Food Sci Emerg Technol 2016; 33: 387-396

[63] Seidi Damyeh M, Niakousari M, Saharkhiz M]. Ultrasound pretreatment impact on Prangos ferulacea Lindl. and Satureja macrosiphonia Bornm. essential oil extraction and comparing their physicochemical and biological properties. Ind Crops Prod 2016; 87: 105-115

[64] Taherkhani M, Rustaiyan A, Masoudi S. Volatile constituents of the aeria parts of Ferulago subvelutina Rech. f., Ferulago stellata Boiss., leaves and flowers of Prangos ferulacea (L.) Lindle. and leaves of Ferula ovina (Boiss.) Boiss.: four Umbelliferae herbs from Iran. Asian J Chem 2012; 24: $1601-$ 1606

[65] Razavi SM. Chemical composition and some allelopathic aspects of essential oils of (Prangos ferulacea L.) Lindl at different stages of growth. J Agr Sci Tech 2012; 14: 349-356 
[66] Razavi SM, Nazemiyeh H, Zarrini G, Asna-Asharii S, Dehghan G. Chemical composition and antimicrobial activity of essential oil of Prangos ferulaceae (L.) Lindl from Iran. Nat Prod Res 2010; 24: 530-533

[67] Masoudi S, Eghbali H, Abadi VK. Volatile constituents of the aerial parts of Ferulago subvelutina Rech. f., Ferulago stellata Boiss., leaves and flowers of Prangos ferulacea (L.) Lindle. and leaves of Ferula ovina (Boiss.) Boiss. Four Umbelliferae herbs from Iran. J Ess Oil-Bearing Plants 2016; 19: 592-605

[68] Bertoli A, Pistelli L, Morelli I, Spinelli G, Manunta A. Constituents of Cachrys ferulacea oils. J Ess Oil Res 1998; 10: 533-536

[69] Ali Massumi M, Fazeli MR, Alavi SHR, Ajani Y. Chemical constituents and antibacterial activity of essential oil of Prangos ferulacea (L.) Lindl. fruits. Iran J Pharm Sci 2007; 3: 171-176

[70] Menghini A, Cagiotti MR, Montanarella L, Fischer FC, Bos R. The essential oil of the fruit of Prangos ferulacea Lindley. Essenze. Derivati Agrumari 1987; 57: 34-40

[71] Başer KHC, Ermin N, Adiguzel N, Aytac Z. Composition of the essential oil of Prangos ferulacea (L.) Lindl. J Ess Oil Res 1996; 8: 297-298

[72] Yousefi K, Hamedeyazdan S, Hodaei D, Lotfipour F, Baradaran B, Orangi M, Fathiazad F. An in vitro ethnopharmacological study on Prangos ferulacea: a wound healing agent. Bioimpacts 2017; 7: 75-82

[73] Sajjadi SE, Shokoohinia Y, Gholamzadeh S. Chemical composition of essential oil of Prangos ferulacea (L.) Lindl. roots. Chemija 2011; 22: 178180
[74] Doković DD, Bulatović VM, Božić BD, Kataranovski MV, Zrakić TM, Kovacević NN. 3, 5-Nonadiyne isolated from the rhizome of Cachrys ferulacea inhibits endogenous nitric oxide release by rat peritoneal macrophages. Chem Pharm Bull 2004; 52: 853-854

[75] Evergetis E, Michaelakis A, Haroutounian SA. Exploitation of Apiaceae family essential oils as potent biopesticides and rich source of phellandrenes. Ind Crops Prod 2013; 41: 365-370

[76] Amiri H. Chemical constituents and antibacterial activity of essential oil of Prangos ferulacea (L.) Lindl. J Med Plants 2007; 6: 36-41

[77] Sefidkon F, Khajavi MS, Malackpour B. Analysis of the oil of Prangos ferulacea (L.) Lindl. J Ess Oil Res 1998; 10: 81-82

[78] Mohammadhosseini M. Chemical profile and antibacterial activity in hydrodistilled oil from aerial parts of Prangos ferulacea (L.) Lindl. and prediction of gas chromatographic retention indices by using genetic algorithm multiple linear regressions. Asian J Chem 2012; 24: 3814-3820

[79] Sümer Ercan F, Bas H, Koc M, Pandir D, Oztemiz S. Insecticidal activity of essential oil of Prangos ferulacea (Umbelliferae) against Ephestia kuehniella (Lepidoptera: Pyralidae) and Trichogramma embryophagum (Hymenoptera: Trichogrammatidae). Turk J Agric For 2013; 37: 719-725

[80] Razavi SM, Nazemiyeh H, Zarrini G, Asna-Asharii S, Dehghan G. Chemical composition and antimicrobial activity of essential oil of Prangos ferulaceae (L.) Lindl from Iran. Nat Prod Res 2010; 24: 530-533 